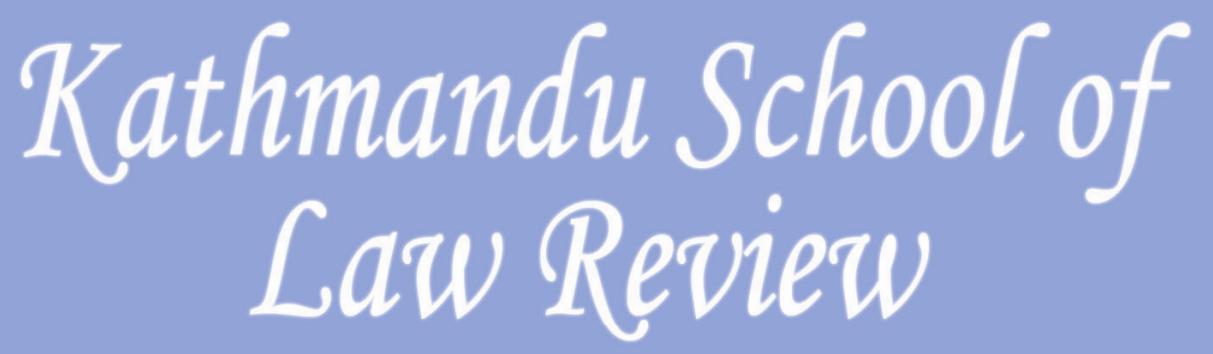

ISSN 2091-2110

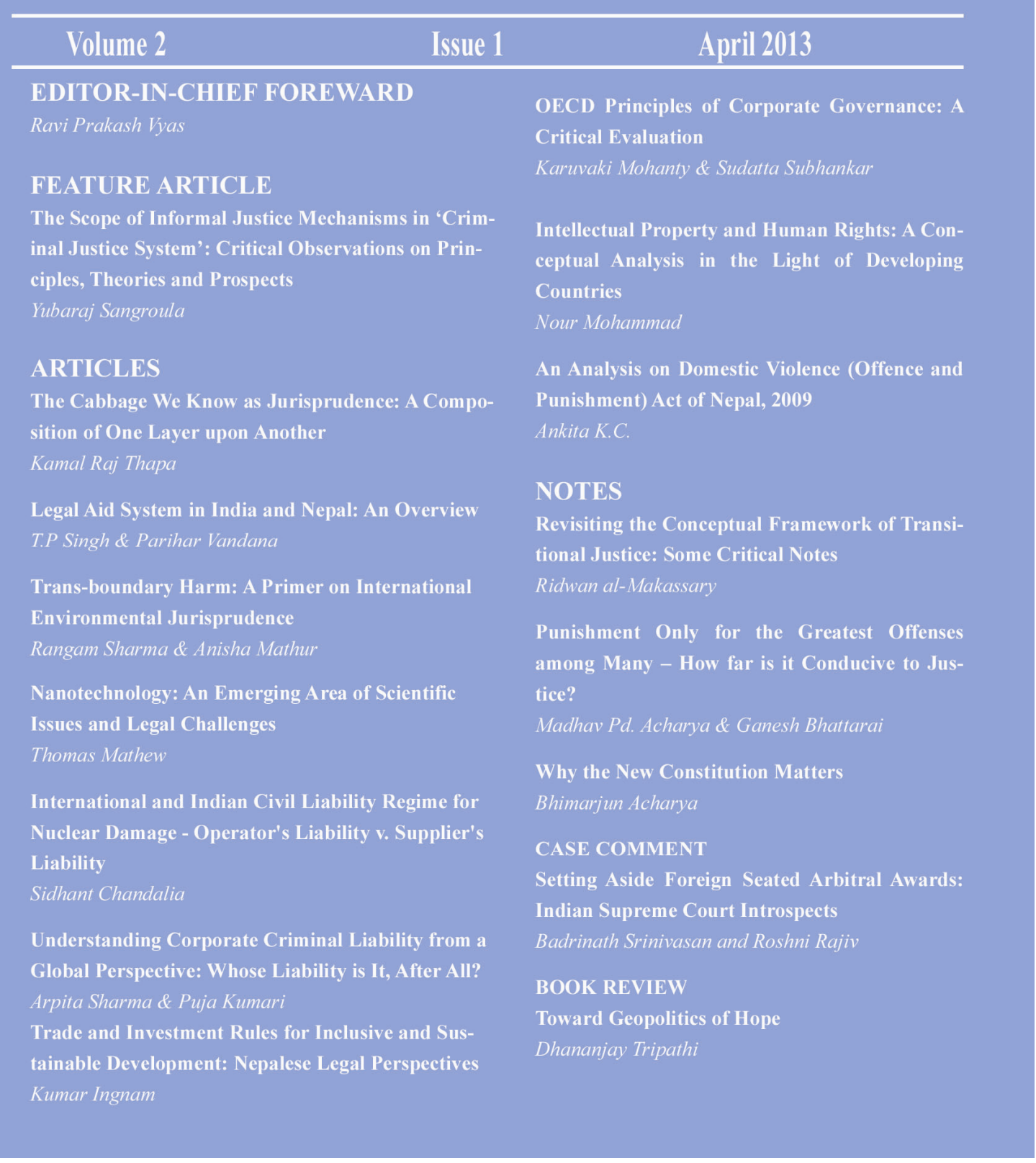




\title{
Trade and Investment Rules for Inclusive and Sustainable Development: Nepalese Legal Perspectives
}

Kumar Ingnam ${ }^{1}$

\begin{abstract}
Sustainability of development and making investment sustainable are reinforcing and correlated. The investor does not invest unless their investment is permitted and protected by the laws and policies of the host state. There exist a number of principles for investment policymaking for sustainable development within which relationship between investors, host states and local communities is a key requirement. Environmental sustainability, social equity and inclusiveness and economic growth are reinforcing and complementing each other which are the three pillars of sustainable development. Nepal had, at the time of WTO accession, confirmed to amend trade related investments measures regime i.e. Foreign Investment and One Window Policy 1992, Industrial Policy 1992 and others, to ensure the compliance with the WTO Agreement on Trade Related Investment Measure (TRIMS). By now, the laws of Nepal, except few, are in compliance with the WTO standards. Nepal has some prospective areas of investment, mostly based on agriculture and service business. Trade and investment with sustainable development, is a pragmatic approach which encourages upgrading policies and laws. However, investment policy alone cannot provide a 'one-size-fits-all' solution for all economies that depends on the eco-socio-political conditions of individual countries.
\end{abstract}

\section{Introduction}

Trade is injected and enhanced by investment. Investment relies on the structure of rules that permits and protects the investors. The cyclical chain relation of trade, investment, and rule could hardly be separated from one another. The whole focus of investment is to get more benefit that is used for the development, economically as well as competitively, which again turns into investment. Sustainability of development and making investment sustainable are reinforcing and correlated. However, it was considered mutually exclusive in the past, a root cause for not solving related problems. As a simple analogy, development is impossible without investment and the investment does not survive without sustainability of development. Sustainable development means the fulfilment of well planned, continued and

Associate Professor at Kathmandu School of Law, Purvanchal University, Nepal. 
high quality investment in any country. Insufficient and inappropriate investment undermines the need of the communities and curtails domestic development as well. Development without ownership and trade for just influx of money from another country often turns to instability. The trio terminologies reinforce one to another, and serve numbers of issues. ${ }^{2}$

The investment flows can improve and help to develop any country. But the investor does not invest unless their investment is permitted and protected by the laws and policies of the host state. The process of investment, repatriation of the investment or any profit earn from the investment and dispute settlement process, in case of any dispute arises in future, should be very simple as well as supportive to them. However, it is a hard bone to orient investors and traders for sustainable development. Trade and investment is a reflection and motivation nudged by an interest and streamlines their interest to the development, which is sustainable and is really difficult in terms of legislation, investors' motivation, supervision and implication.

\section{Role of Trade, Investment and Development}

Trade is an effective means of resources mobilization. Recent trade development is on the verge of slashing down tariff as well non tariff barriers, and practicing non discriminatory treatment of goods and services. Choice for investment should be transparent and competitive. Foreign direct investment is a process of mitigating investment problems and supplementing gaps and transferring knowledge and skills. Skill, knowledge and investment boost trade and which in turn generates more revenue, a reliable source of substantive development. In this respect multilateral, regional and unilateral agreements do have special importance. The amount of national or foreign investment inflow in any host country depends on standard, conducive and compatible policies, legal provisions and economic environment to the investor. At the same time investor is supposed to be liable for their special obligation to the community or nation where they profit from the investment.

Trade diversification and facilitation could enhance trade. There is a direct linkage among MDG GOAL 8, trade facilitation, market access and commitment of market liberalization of particular countries. Therefore, globalization and liberalization are the dynamics for the achievement of sustainable development.

\section{Initiation for trade, investment and development}

The GATT 1947 is a cut of point for the modern collective beginning towards the development of trade that ultimately got its final shape after numbers of negotiations resulting in the formation of World Trade Organization (WTO). The relationship between

2 Including fight against worldwide severe threats to the sustainable development i.e. chronic hunger, malnutrition, foreign occupation, armed conflict, illicit drug problems, organized crime, corruption, natural disasters, illicit arms trafficking, trafficking in persons, terrorism, intolerance and incitement to racial, ethnic, religious and other hatreds; xenophobia; and endemic, communicable and chronic diseases, in particular HIV/AIDS, malaria and tuberculosis. 
international trade, investment and sustainable development further developed after the Earth Summit of 1992 held in Rio de Janeiro when negotiators faced the task of defining how sustainable development would be operationalized ${ }^{3}$ The World Summit on Sustainable Development held in Johannesburg, South Africa, in September 2002, revisited the links between trade, finance and sustainable development. ${ }^{4}$ Numerous serious issues were discussed at the summit, such as poverty eradication, sustainable patterns of consumption and production, protection and management of the natural resource based on economic and social development, sustainable development in a globalizing world, health and sustainable development, implementation and institutional framework for sustainable development at, regional and national level. ${ }^{5}$ The summit also discussed linkage between trade and sustainable development with the decision of the Doha Round negotiations. The implementation of the Monterrey Consensus on Financing for Development ${ }^{6}$ of Johannesburg Summit was concerned to analyse and promote open, transparent, equitable, rules-based, predictable and non-discriminatory multilateral trading and financial systems in the pursuit of sustainable development. The whole focus on the sustainable development envisaged by these summits is to intermingle and interconnect issues that reinforce and revamp.

The consensus has declared that eradication of poverty, promotion of sustainable development and advancement of inclusive and equitable global economic system are the goals. It attempts to attain effective use of financial resources achieving national and international economic conditions needed to fulfil development goals enshrined in Millennium Development Goal (MDG). ${ }^{7}$ They had committed to the sound policies, good governance and the rule of law, mobilize domestic resources promoting international trade as

3 Building on an international consensus that recognized the importance of a supportive international climate of economic cooperation, negotiators made clear in Chapter 2 of Agenda 21 that an open, equitable, secure, non- discriminatory and predictable multilateral trading system must be ensured to deliver on the promises of sustainable development. Signatories also agreed at the time that trade policy should not operate at cross-purposes with international efforts to curtail environmental degradation or promote development.

4 The summit has focused on the indivisibility of human dignity through decisions speedily increase access to basic requirements such as clean water, sanitation, adequate shelter, energy, health care, food security and the protection of biodiversity. At the same time, collective work to gain access to financial resources, benefit from the opening of markets, ensure capacity-building, use modern technology to bring about development and make sure that there is technology transfer, human resource development, education and training to banish underdevelopment forever. See UN, Report of the World Summit on Sustainable Development (26 August-4 September 2002) A/CONF.199/20, para. 18.

$5 \quad$ Ibid resolution 2.

6 International Conference on Financing for Development, Monterrey Consensus of the International Conference on Financing for Development (Report, 18-22 March 2002)

7 Ibid para 1.1, 1.3; The MDG emphasis the role of developing countries to ensure their own development, and compliance of the commitment of developed countries to support through aid, debt relief. The developed countries again agreed Doha Development Agenda (DDA) in 2001 for better trade opportunities providing numbers of flexibilities, facilities directly supportive to the economic development of developing and LDCs however the achievement of the MDGs and DDA remains stalled. Most aspects of trade, from intellectual property rights to agricultural products, are addressed by different international processes. 
an engine for development in order to increase international financial and technical cooperation for development. In addition to that, external debt relief with enhancement, coherence and consistency of the international monetary, financial and trading systems are other commitments they have committed to. ${ }^{8}$

The conference has realized that the commitment cannot be fulfilled until concerned country feels their special role of upgrading national policies and development strategies compatible with the global economic system. That is why mobilization of domestic financial resources pursuing sound microeconomic policies and avoiding economic fluctuation with effective, efficient, transparent and accountable system for mobilizing and managing public resources is essential. Maximum utilization of banking and financial institutions and micro finance would be helpful for the domestic utilization of resources. Foreign direct investment is one of the reliable sources to meet the need and compliment insufficient domestic resource mobilization. Foreign direct investment contributes to finance sustainable economic growth over a long term. It is especially important for transfer of knowledge and technology, to create jobs, to boost overall productivity, enhance competitiveness and entrepreneurship and ultimately eradicate poverty through economic growth and development.

Furthermore, the commitment to the Programme of Action for the Least Developed Countries (LDCS) for the Decade 2001-2010, adopted by the 3rd UNCTAD, held in Brussels May 2001, and the Global Programme of Action for the Sustainable Development of Small Island Developing States (SIDS) are the initiation to the development of LDCs and SIDS. Fourth UN Conference on LDCs in May 2011 was adopted the Istanbul Programme of Action for the LDCs 2011-2020 with a strong focus on productive capacity-building and structural transformations core elements to achieve more robust, balanced, equitable, and inclusive growth and sustainable development.

The role of FDI in the development process enhancing foreign investment on sustainable development and inclusive growth, while underlining the importance of stable, predictable and enabling investment climates are sufficiently discussed in the international forum, especially at UNCTAD XIII Conference held in 2012 and other previous conferences organized by the same.

\section{Requisite for Trade, Investment and Development}

Trade and investment agreements share and address number of principles. They discourage protectionism and discrimination between foreign and domestic products and services. Promotion of market access reducing tariffs, quotas and other non-tariff barriers, and harmonization of international standards as well product-related health and safety measures are the prerequisites for trade and investment. Obviously, without free and fair trade of goods and free movement of entrepreneur/individuals and investment, neither trade nor sustainable

$8 \quad$ Ibid para 1.4. 
income for development is guaranteed. Insufficient investment is the main stumbling block that effectively slows the process of development whereas unguaranteed trade environment discourages both trade and investment. Thus, investment and environment are pre requisite for trade and investment. The development is a response of both. Their connotation is discussed below:

Trade: Trade is an effective dynamic for economic and physical development. But the trade must be based on universal, uniform and standard rules. Additionally, there should be open, non-discriminatory and equitable multilateral trading system. Trade liberalization, a basic requirement, could stimulate development worldwide, benefiting countries at all stages of development. The standard stipulated by WTO, i.e. eliminating or slashing down trade barriers including tariff and non tariff barriers, trade-distorting subsidies, providing market access and non discriminatory treatment are perennial and protective measures such as antidumping, countervailing are reasonably and scientifically needed. Proper use of sanitary and phyto-sanitary measures, technical barriers and sufficient encouragement to trade liberalization in labour intensive manufactures and agricultural products, trade in services, recognition and protection of intellectual property rights especially traditional knowledge and other intellectual property, optimum practice of special and differential treatment provisions for developing and least developed countries, and encouragement and effective application of mode 4, movement of natural persons can help to render trade, investment and development effective.

Countries should have a transparent, stable and predictable investment climate, with proper enforcement mechanism to enforce investment contract. Strong legal provision to protect property right in host country, sound macroeconomic policies and institutions that allow, support the investors for businesses at domestic and international level. These are the factors that determine the future of investment. Efficient and profitable business attracts inflow of foreign investor automatically. The sound and attractive national economic policy and regulatory frameworks encourage investor if the provisions sufficiently assure that the investors will have no pressure of human resource, double taxation, corporate governance, accountability and competitive environment.

Investment: Sound microeconomic policy for tackling price stability, balance of payment, sustainable fiscal and external balance, avoids inflation and other fluctuations, and effective capital markets for efficient banking, insurance and equity arrangement are the prerequisites of investment. Additionally, economic and social infrastructure for social service as well as social protection for the delivery of health, education, food, shelter and social security i.e. employment, pension etc. are support systems of the investment.

The role of foreign direct investment contribute sustainable economic growth in a long run transferring technology, creating jobs, enhancing competitiveness, ultimately economic growth as well development. But the problem is to attract investor. Investor can be attracted if there is transparent, predictable and stable investment environment reinforcing proper 
enforcement mechanism, enshrined on effective and efficient legal protection. Increased foreign direct investment boosts the trade and the trade in turn boosts economic growth, these are the base of development and sustainability of development.

Investment is guided by investment policy. But for long, investment has been thought needed for business and profit rather than special responsibility to the society. As a result, some of problems were identified for improvement, i.e. environmental pollution, labour issues, addressing local issues, transparent funnelling and repatriation, solution of an immediate problem ignoring mediate issues. A fresh start to address the problems was awaited long back. New Generation Investment Policy (NGIP), a new alternative, is a comprehensive set of investment policy that places inclusive growth and sustainable development at the heart of efforts to attract and benefit from investment. ${ }^{9}$ It focuses on sustainable development with more concern and responsibility of investors on environmental, social and poverty alleviation. It is a new concept as it encourages the investor to be a part of sustainable development rather simple CSR. It failed since ODA and foreign (direct) investment had no consistency on goal, harmonization and coordination on policy and synergies with for economic development. It was undertaken in order to reinforce each another for the development and sustainability of such development. ${ }^{10}$

NGIP strives to create synergies with wider economic development, industrial policies, and achieve seamless integration in development strategies; foster responsible investor behaviour and incorporate principles of CSR; ensure policy effectiveness in their design and implementation and in the institutional environment within which they operate. ${ }^{11}$

The challenges could be addressed by developing comprehensive Investment Policy Framework for Sustainable Development (IPFSD) that should consist of: a set of Core Principles $^{12}$ for foreign investment policymaking, guidelines for investment policies at the

9 NGIPs are characterized by: i) a recognition of the role of investment as a primary driver of economic growth and development and the consequent realization that investment policies are a central part of development strategies; ii) a desire to pursue sustainable development through responsible investment, placing social and environmental goals on the same footing as economic growth and development objectives, and iii) a shared recognition of the need to promote responsible investment as a cornerstone of economic growth and job creation is giving renewed impetus to efforts to resolve, in a comprehensive manner, long-standing issues and shortcomings of investment policy that may hamper policy effectiveness and risk causing uncertainty for investors. These three broad aspects of 'new generation' investment policies translate into specific investment policy challenges at the national and international levels. UNCTAD, Investment Policy Framework for Sustainable Development (UN 2012) 6.

10 Ibid 5.

11 UNCTAD, World Investment Report 2012: Towards a New Generation of Investment Policies (UN2012) xxiv-xxv.

12 They comprise the Universal Declaration of Human Rights and the UN Guiding Principles on Business and Human Rights, the Convention on the Establishment of the Multilateral Investment Guarantee Agency, the World Bank Guidelines on the Treatment of Foreign Direct Investment, the UN Global Compact, the OECD Guidelines for Multinational Enterprises and the ILO Tripartite Declaration of Principles concerning Multinational Enterprises and Social Policy, and several WTO-related agreements, including the GATS, the TRIMs Agreement and the Agreement on Government Procurement. 
national level and options for the design and use of IIAs. The policies should include the establishment, treatment and promotion of investment addition to the national and international policies, because coherence between the two is fundamental. The IPFSD focuses on direct investment in productive assets, and portfolio investment is considered only where explicitly stated in the context of IIAs.

\section{Core principles for Investment Policymaking for Sustainable Development ${ }^{13}$}

The core principles are inclusive growth and sustainable development, policy coherence and synergy at both national and international level, dynamic policy making, balanced right as well as obligations, regulatory provisions, open, stable and predictable entry conditions for investment, adequate protection to the investors without discrimination, investment promotion and facilitation with sustainable development design to minimize the risk of harmful competition for investment, facilitate adoption of and compliance with best international practices of corporate social responsibility and good corporate governance and international cooperation. The core principles also include regular review for the effective promotion of changing development dynamics and minimization of harmful competition for investment. The rights and obligations of States and investors in the interest of development for all and regulatory right subject to international commitment minimizing negative effects are other principles of sustainable development.

Relationship between investors, host states and local communities is a prime requirement for sustainable development. Investment policy coherence for productive capacity building and sensitive industries protection are complementary principles that exist together. Investment policy coherence for productive capacity building, which includes investment on human resource development, infrastructure, technology dissemination and enterprise development, is more general and non discriminatory whereas sensitive industries protection, a common option of investment policy, generally authorized by decision of the host country, to protect sensitive industries, is specific and logo centric. This practice is under big debate as to whether the protection enhances or restricts the movement of liberalization and openness.

While designing sustainable development activities, investment-specific policies and regulations should include the policies of establishment, operations, treatment and protection of investments and investment promotion and facilitation for their security, and also include investor responsibilities such as corporate responsibility. Such investment and guaranteeing compliance should be with international core standards and investment promotion accompanied by the use of incentives that should corroborate the interest of inclusive and sustainable development. Special attention should be given to the issues of double taxation, competition, labour standards, environmental impact and access to land

13 UNCTAD (n 11) xxvi. 
aiming minimal impact of investment. Public governance and institutional capacitybuilding could contribute to the investment policy effectiveness. ${ }^{14}$

New generation investment policies aim to systematically integrate sustainable development and operationalize it better.

\section{Features of Sustainable and Inclusive Growth}

Sustainability of growth depends on a resource-efficient, greener and more competitive economy. ${ }^{15}$ Environmental sustainability, social equity and inclusiveness and economic growth are reinforcing and complementing each other. ${ }^{16}$ Sustainability survives on the social, economic and environmental sustainability. Economic and social sustainability, on the one hand, and social and environmental sustainability, on the other, have been found to be not only compatible, but also largely corresponding. ${ }^{17}$ Thus, the three pillars are considered the pillars of sustainable development. Nature has been providing human needs in a natural form and it is the duty of human being to use these natural products with due care and respect for the nature. Human conscience should be used for transforming themselves on the natural form without bigger deviation of such products as all material things in this world are creations of nature. They just represent the nature differently, in different forms. Inclusiveness is not a new paradigm rather concerns balanced use of natural resources. 'Grow dirty and clean up later' is a misleading conception that has substantially damaged the nature and environment fuelling the disasters and resulting 'competition to the bottom'.

Sustainable development does not induce damages, in contrast has minimum effect on the environment, biodiversity and natural resources and is helpful to minimize the level of vulnerability to natural disasters. Protection of environment, biodiversity, natural resources ultimately promote a green economy, generate growth, create jobs and help reduce poverty making resource efficiency and low-carbon emission in the environment. People will have less health risk because of consuming fresh and least contaminated organic food that will save millions of people and billions of investment on health alone. The amount may invest for more creative areas. Development could be a good indicator for the improvement of developing countries to the employment and economic, social and territorial cohesion. However, political stability, good governance, security, the respect for human rights, a conducive regulatory and business environment, a well educated, healthy and creative population, the sustainable use of scarce natural resources, physical infrastructure, implementation of labour standards and beneficial international trade also affect the level of sustainability of any development.

\footnotetext{
$14 \quad$ UNCTAD (n 13) xxvi.

15 'Empowering People for Inclusive Growth' (European Union) 1 <http://eudevdays.eu/sites/default/files/EDD12_EPIG_25092012pdf〉 accessed 28 April 2013.

16 UNIDO, Industry: Inclusive and Sustainable Development (Vienna International Centre 20127.

17 World Bank, Inclusive Green Growth: The Pathway to Sustainable Development (2012) 2.
} 
Inclusive growth means raising the pace of growth and enlarging the size of the economy, while levelling the playing field for investment and increasing productive employment opportunities. It focuses on ex-ante analysis of sources, and constraints to sustained, high growth, and not only on one group, the poor.

The analysis looks for ways to raise the pace of growth by better utilization of parts of the labour force trapped in low-productivity activities or completely excluded from the growth process. ${ }^{18}$ Inclusion in health, financial, education and social protection are the biggest issues of inclusion.

\section{Trade and Investment Laws in Nepalese Perspectives}

Nepal had, at the time of WTO accession, confirmed to amend trade related investments measures regime, i.e. Foreign Investment and One Window Policy 1992, Industrial Policy 1992, Industrial Enterprises Regulations, Industrial Enterprises Act 1992, Foreign Investment and Technology Transfer Regulations and the Foreign Investment and Technology Transfer Act 1992 to ensure the compliance with the WTO Agreement on Trade Related Investment Measure (TRIMS). ${ }^{19}$ Nepal had ensured that, from the date of accession, TRIMS would not be introduced unless it confirmed with the requirements of the Agreement $^{20}$ and would notify and provide information on the activities of State Trading, i.e. Nepal Oil Corporation and Salt Trading Corporation in accordance with Article XVII of the GATT and the Understanding. Nepal would apply its laws and regulations governing the trading activities of enterprises with special or exclusive privileges and would otherwise act in full conformity with the provisions of Article XVII of the GATT 1994 and Article VIII of the GATS. ${ }^{21}$ By now, the laws of Nepal, except few, are in compliance with the WTO standards. Following are the cornerstone legislations in this regard:

\section{Foreign Investment and One Window Policy $1992^{22}$}

The policy permits 100 percent investment for large and medium size industries only, whereas in case of small and cottage industry only technology transfer is permissible.

$18 \quad$ European Union (n 15 ) 2.

19 Nepal has committed to standardizing 39 legislations, including Act, Rules, policy and ratification of convention.

20 WTO, Report of the Working Party on the Accession of the Kingdom of Nepal to the World Trade Organization (28 August 2003) WT/ACC/NPL/16 para 108-109.

$21 \quad$ Ibid para 111.

22 Nepal did not attract much foreign direct investment (FDI) in spite of policy reforms initiated in the early 1990s. This is partly because a small, least developed, landlocked, mountainous country has little to offer to investors. Nevertheless, other similarly situated countries are receiving more investment than Nepal. Numbers' of advantages Nepal have namely privileged access to a well-disposed neighbouring country with a large market; a low wage, trainable workforce; a flourishing local entrepreneurial culture in both small and large business; and established international recognition thanks to tourist landmarks. Nepal's temperate climate is also ideal for cultivating medicinal herbs, whose market has seen phenomenal expansion in recent years. These advantages can make attractive investment packages. 
Franchising and technology transfer requires government permission. ${ }^{23}$ Fifteen percent tax is imposed on the income, income from interest, foreign loan, royalties, technical and management fee and income earned from export under Industrial Enterprises Act. ${ }^{24} \mathrm{No}$ income tax is levied on income earned from exports. Double taxation relief, reimbursement of custom duties, excise duties and VAT levied on raw materials of export oriented industries are other taxation provisions. Investors can repatriate amount received by sale of equity investment, benefit or dividend received from the investment, principal or interest of the foreign loan, amount received under technology transfer agreement, amount received as compensation for acquisition of property. Any foreigner working as expatriate employee may repatriate 75 percent of the salary received at work.

Foreign investors or valid representatives will get non-tourist visa as long as the investment remains. Six month non-tourist visa is granted to investors who conduct research for investment, and permanent residence visa is granted to the investor and his/her dependence who invests at least USD 200, 000 or more.

Foreign individuals are not permitted to own land, but resident companies may do so even if foreign-owned. A further ad hoc restriction is that foreign ownership of commercial banks is limited to 66 per cent. Any industries listed in 'negative list' are not permitted for foreign investment. The 'negative list' are of two, as listed in part $\mathrm{A}^{25}$ which only the parliament can change as listed in part $B^{26}$ which can be only changed by government. The negative list contains consultancy services such as management, accounting, engineering and legal Services. Thus, international accounting and law firms, and other professionals, cannot practice from an establishment in Nepal.

Nepal has concluded relatively few bilateral investment treaties (BITs) but surprisingly, there is no BIT with India, Nepal's major investment and trade partner, although there has been a treaty of friendship in place since the 1950s. Considering the need of conducive trade environment the policy is supposed to fulfil a number of constraints such as discriminatory, double payment to register a trademark, build-operate-transfer (BOT) schemes to the foreign investor that is generally not required generally rather renew of operation license.

$23 \quad$ Foreign Investment and One Window Policy 1992 para 4.

24 Ibid para 6.

25 That includes cottage Industries, personal Service business, i.e. hair cutting, beauty parlour, tailoring, driving training etc., arms and ammunition industries, explosives, gunpowder, industries related to radioactive materials, real estate business (excluding construction industries), motion pictures business, security printing and currencies and coinage business.

26 That includes retail business except the retail business instantly conducted more than two countries as international transaction, bidi, internal Courier service, atomic energy, poultry farming, fisheries, beekeeping beauty paler, domestic food processing methods in rent, local catering service and rural tourism. 


\section{Industrial Policy 2010}

The policy has replaced the previous Industrial Policy $1992^{27}$ as a part of compliance to the WTO accession, in conformity with WTO Agreements on Subsidies and Countervailing Measures and on Trade Related Investment Measures. The policy has numbers of features. ${ }^{28}$ The policy aims to promote value-added industries, and increase production and productivity. Nepal does not provide direct payments to any manufacturing industry, except certain incentives, such as income tax, VAT, excise duty, and customs duties exemptions or deductions for certain industries. Export tax is levied to protect the environment such as wood export, ensure food security, and discourage trade diversion to India. Addition to that, $13 \%$ VAT, corporate tax, income tax is levied. Its other provisions are:

a. flexible labour policy, no-pay-for-no-work principle, permission for easy exit from business for both domestic and foreigners investors;

b. use of local resources, raw materials, skills, labour and technology making industrial sector sustainable and competitive for comparative advantage

c. deduction of taxable amount expense on research and development, and tax and income rebate incentives and easy credit to export-oriented firms for attraction and security of industrial entrepreneurs $;^{29}$

d. promotion, protection, development and expansion of micro enterprises, cottage and small industries through capacity enhancement, availability of industrial infrastructure and protection of their intellectual property; ${ }^{30}$

e. protection of industry through antidumping and countervailing duty within the bound rate (but the law is still to be founded);

f. initiation for the modification of existing trade agreement with China and India in order to keep trade balance $;^{31}$

g. financial access to cottage, small industries through micro enterprise, cottage and small industries development fund, rural self employment fund, equity fund, credit guarantee fund; ${ }^{32}$

27 The policy had also emphasized on the development of export-oriented industries and industries using local resources, and its important element was to reduce unemployment. The Industrial Enterprises Act 1992 was implemented under this policy. Section 15 of this Act has provided for certain priorities areas forsubsidy such as tax reduction and excise duty rebate of up to 35 percent for the industries established in remote, undeveloped and underdeveloped areas for export oriented products. But the policy did not meet its objectives hence, Nepal Government has bundled up the policies within the tenth five year plan of 2002.

28 Industrial Policy, para 7.1-7.5, 8.1-8.19.

29 Industrial Policy (n 28) para 9, 10.32.

$30 \quad$ Ibid para 9.

$31 \quad$ Ibid para 10.1-10.9. 
h. industrial planning for Karnali corridor, industrial corridor, industrial district, industrial cluster and industrial village, and development of raw material based industries and herb and fruit processing industries in remote and hilly area; ${ }^{33}$

i. tax holidays for 10,7 , and 5 years for firms that invest, respectively, in highly underdeveloped (21 districts), undeveloped (15 districts) and less developed (24 districts) areas; ${ }^{34}$

j. promoting special economic zones (SEZs) through, inter alia, the enactment of a special law on SEZs, and emphasis on some institutional arrangement such as investment board, one stop service center, ${ }^{35}$ tndustrial promotion board, industrial district management authority, industrial human resources development Institution and Nepal business forum;

k. establishment of effective body for the protection of industrial intellectual property right i.e. collective mark, trademark; ${ }^{36}$

1. establishment of Business Incubation Center based on agriculture and non-timber forest based raw materials in collaboration with FNCCI and Cottage and Small Industries Association, National Macro Entrepreneurs Group; and provision of angel fund and venture capital fund; ${ }^{37}$

m. 'One Village One Product' policy and encouragement for cooperative for such industries ${ }^{38}$

n. Institutization of a one-window policy for all industrial activities (the policy will be substituted by one stop service center) $;^{39}$ and

o. Reforming the Nepal Industrial Development Corporation, which is currently inactive due to inadequate capital and weak management. In addition, the Industrial Policy 2010 aims to promote value-added industries and facilitate supply and adoption of new technology to increase production and productivity.

The policy has defined and classified industries such as industry based on agriculture and forestry, production oriented, export oriented, energy oriented, mining oriented, tourism oriented, construction, information and communication technology and service. ${ }^{40}$

Ibid para 11.4 .

Ibid para 10.10-10.16.

Nepal is divided into 75 administrative districts

For permission on establishment, registration, expansion and exit of an industry and to ensure the availability of services in simple and transparent manner within the specified period (para 10.20)

See Ibid para8.18-8.19, 9.8, 10.38-10.40, 11.5 .

Ibid para 11.20-11.25.

Ibid para 11.6-11.10, 11.16.

Ibid para 10. 23. 
Classification of industries in terms of investment is also defined on the categories namely micro enterprise (with annual transaction less than two million), traditional cottage industries, small scale industries (fixed asset of up to five million), medium scale industries (fixed asset of up to fifty million), large scale industry (fixed asset of more than one hundred and fifty million). ${ }^{41}$ Schedule 7 has specified prioritized industries which need to be reviewed every five years and could be changed by government on the recommendation of Industrial Promotion Board, if needed. There is no need of permission to establish, extend and diversify and modernize industries other than the industries referred to in schedule 8 that causes adverse impact on security, public health and environment. ${ }^{42}$ In case of permission to be obtained from DOI, such would be provided within 30 days from the date of application. A micro enterprise and traditional cottage industry should inform the local body within one month of its operation and should register within 15 days of submission. It does not require permission except for environment impact assessment as provided in schedule 8 . Cottage and small industry should register at the Office of the Cottage and Small Industries Development Board located in the district.

\section{Trade Policy 2009}

Government of Nepal introduced a new Trade Policy in April, 2009 replacing the Trade Policy 1992. It is consistent with the principles of WTO and adheres to the principles of liberal, open and transparent economic system. It emphasizes on private sector-led competitive economy. The main objective of this policy is to increase contribution of trade sector in national economy and thereby reduce poverty and accelerate economic growth. The new Trade Policy, besides emphasizing trade in goods, has also duly recognized trade in services and intellectual property equally as potential trade sectors for Nepal. This policy includes an exhaustive list rangind from institutional strengthening to legal and procedural reforms in order to create conducive environment for trade in the country. These measures and provisions are supposed to enhance country's trade both internally and externally. The policy has broadly classified potential Nepalese exports into two categories: Special Focus Area and Thrust Area Development. Four products are included under special focus area, most of which have already been established in the export market. Newly emerging fifteen products have been listed under the second category. Currently, the Government is preparing a detailed action plan to expedite the implementation of this policy.

\section{Foreign Investment and Technology Transfer Act (FITTA) 1992}

The law allows the repatriation of capital investments and profits by foreigners. Sections 2, 3 and the annex of the FITTA are relevant for all foreign investment and cover the major criteria for the permission of foreign investment. Its first amendment of 1996 has added

Ibid para 12.2.1-12.2.9.

Ibid para 12.3.1-12.3.5.

Ibid para 13, 14. 
some simplification in procedure and openness to foreign investors. Except enlisted areas of investment i.e. cottage industries, arms and ammunitions, security printing, currencies and coinage, retail business, trekking agencies, rural tourism, beauty parlour, domestic food processing methods in rent, consultancy services of more than 51 percent ownership, foreign investor are permitted to invest in Nepal. Those who are interested to invest should get approval from Department of Industry, filling an application for foreign investment or technology transfer in the prescribed form along with the prescribed particulars. It grants permission directly in the case of an industry with fixed assets up to 500 million Rupees and in accordance with the decision of the Industrial Promotion Board in the case of an industry with fixed assets of more than one billion Rupees within 30 days from the date of application. ${ }^{43}$ Foreign individuals are not permitted to own land but resident companies can go ahead with it. Foreigner can invest up to 80 percent in banking service but is limited to 67 percent for other financial institutions. FITTA guarantees full repatriation of the amount received from the sale of equity, profits, or dividends and interest on foreign loans, and the repatriation of the amount received under an agreement for the transfer of technology. ${ }^{44}$ Foreign investors are granted a business visa as long as their investment is retained. A resident visa would be provided for a foreign investor, and dependents that at a time make an investment in excess of US\$100,000 or equivalent and retains it. ${ }^{45}$

\section{Investment Board Act 2010}

Investment Board formed under this $\mathrm{Act}^{46}$ invites mega project (infrastructure or service of at least having fixed capital of ten hundred million rupees) ${ }^{47}$ and provides approval for investment of any sector of investment by direct negotiation (of either non selective proposal, or non possibility of competition, or of new concept or technology) ${ }^{48}$ on the proposal of investment. The Board evaluates, negotiates and concludes agreement with an investor on the basis of terms and conditions approved by the Board, and motivate for implementing the project, monitors the implementation, solves the problems, provides specified economic or non-economic facility, submits suggestions to the Board for reform

FITTA 1992, s.3(2), 3(3).

Ibid s 5.

Ibid s 6 (2)

Investment Board Act 2010, s 3.

Ibid s 9. That includes Investment to be made in fast track road, tunnel, railway, rope way, trolley bus as specified by the Government of Nepal, construction of international, regional level airport and modernization and management of the running airport, management and refinement plant of dump, chemical fertilizer production factory, plant of petroleum refinery, construction of big bridge, Bank and financial institution having more than fifty one percent or in the establishment or operation of insurance or reinsurance company, medical college, hospital or nursing home having more than three hundred beds, hydro power project of Five hundred or more megawatt, establishment of special economic zone, export promotion or refinement zone, special industrial zone or information technology park. 
and gives special priority to investment. ${ }^{49}$ The Act also provides guarantee against nationalization of the investment. ${ }^{50}$

\section{Industrial Enterprises Act 1992}

This Act has classified industries as manufacturing, energy and agro-forest based mineral tourism, service and construction ${ }^{51}$. Such industries are divided into cottage, small, medium, large as to the nature and amount involved. ${ }^{52}$ Industries set forth in Annex 2, as considered significantly related on the security, public health and the environment should require obtaining permission, ${ }^{53}$ making application to the Department in the prescribed form along with the prescribed particulars. The Department, as per the decision of the Board, grants permission within thirty days from the date of application or informs if it decides not to grant permission for the establishment of the industry. ${ }^{54}$ The Act has designed a thirteen members 'Industrial Promotion Board' under the chairmanship of Industries minister or state minister to make policies, implement and other necessary activities for the promotion of trade. ${ }^{55} \mathrm{~A}$ 'one window committee' consisting eleven members under Director General, Department of Commerce, makes necessary decisions for facilitating availabilities of the facilities and concessions to be enjoyed by any industry under this Act and recommends available infrastructural services such as electricity, water, means of telecommunications, land, road and so on required for the industries. ${ }^{56}$ Numbers of facilities have been offered to the investors under section 15 of the Act. The Act has guaranteed against nationalization of the industry and repatriation of remuneration up to 75 percent by the employee of such industry, who could work for five years, if required, with prior approval of Department of Labour and additional five years for technicians not available in Nepal. ${ }^{57}$

Ibid s 7 .

Ibid s 18(1).

Industrial Enterprises Act 1992, s 3.

Ibid s 4-7.

53 That includes explosives, including arms, ammunition and gun powder, security printing, bank notes and coin industries; cigarette, bidi, cigar, chewing tobacco, khaini industries and industries producing goods of a similar nature utilizing tobacco as the basic raw material and alcohol or beer producing industries. Sectors reserved for nationals mainly in order to promote small entrepreneurs are generally of indigenous skills, resources and technology; cottage industry; personal service business (business such as hair cutting, beauty parlour, tailoring, driving training, etc.); Industries related to radioactive materials; Real estate (excluding construction industries); Motion picture industries (produced in national languages and the language of the nation); Retail business; Travel agency; Trekking agency; Water rafting; Pony trekking; Horse riding; Internal courier services; Atomic energy; Tourist lodging; Poultry farming; Fisheries; Bee keeping; Consultancy services such as management, accounting, engineering and legal services etc.

$54 \quad$ Ibid s 9.

55 Ibid s13.

$56 \quad$ Ibid s 18.

57 Ibid s 21- 22. 
The legislation of Nepal, Foreign Investment and One Window Policy, Industrial Policy and FITTA etc. Have tried their best to address the challenges and provide conducive environment to foreign investment. However, the provisions incorporated are not sufficient to integrate investment policy in development strategies, channel investment to build-up of productive capacity and ensure coherence towards overall development objectives. Nevertheless, the policy has built institutions to implement investment policy for investment policy relevance and effectiveness. The investment provisions of the legislations are not so concrete and consistent with sustainable development objectives that could balance responsibilities of the investors. Despite such lapses dispute settlement mechanism, repatriation and facilities related to are guaranteed.

The core principles stipulated by UNCTAD for the promotion of investment for inclusive growth and sustainable development has been partially adopted. The law has sufficient provisions as regards open, stable and predictable conditions for investment and protect adequately to the establishment and non-discriminatory treatment. The laws are in consistence with basic international standards and norms i.e. rule of law, governance and accountability. The law and policy are only partially successful to promote and facilitate sustainable development goals, compliance with best international practices of corporate social responsibility and good corporate governance and are designed to minimize the risk of harmful competition for investment. Furthermore, it is not able to adapt to the changing development dynamics and minimize negative effects of international commitment.

\section{Prospective Investment in Nepal}

Nepal has some prospective areas of investment, mostly based on agriculture and service business as discussed here:

Agriculture: Nepal Trade Integration Strategy (NTIS) 2010 have identified agricultural products such as lentils, tea, ginger; large cardamom, etc are very potential goods for export. However, any product produced by organic farming has emerging demand within and out of the country. Non agricultural goods/products such as honey, noodles, medicinal herbs/essential oils, handmade paper, silver jewellery, iron and steel, pashmina, wool products, and service business such as tourism, labour services, information technology and business process outsourcing services, health services, education, engineering, and hydroelectricity are other prospective area of business as well investment. Other potential exports are sugar, dairy products, cement, and transformers.

Tourism: Nepal is conducive for mountaineering and trekking. Warm weather, majestic nature and assembles of high peaks are the attraction of mountaineering and trekking. Nepal has eight of the world's fourteen highest mountain peaks including the highest peak in the world-Mount Everest and other high peaks i.e. Kanchenjunga, Lhotse, Makalu, Cho-Oyu, Dhaulagiri, Manaslu and Annapurna. It is home to most rugged and difficult terrain in the 
world and some of the most beautiful trekking routes in the world. It is also the birth place of Lord Buddha and houses varieties of cultures including rare tribes such as the Raute.

Water resources: Nepal is one of the richest countries in water resources. The Himalayan region is the abode of perennial source of water. The Himalayan range above 16000 feet is covered with snow round the year. Around 6000 rivers and rivulets are crisscrossing the country. It has estimated that the capacity of rivers and rivulets could produce $83,000 \mathrm{MW}$ of electricity, of which 43,000 MW is technically viable, which is still far greater than its domestic requirement estimated at 1650 MW by 2020. Interestingly, Nepal is generating about $700 \mathrm{MW}$, below the demand of $900 \mathrm{MW}$.

Nepal Government has prioritized five areas for foreign investment which are hydro electricity, infrastructure and development, agro processing and herbs, tourism and other services and minerals and mine related projects. The Government is further working to develop fifty potential projects which can be recommended to the foreign investors seeking potential projects for investment.

\section{Conclusion}

The trade and investment legislation could be termed inclusive and sustainable when the development fulfils the objectives of MDG goals and serves the basic needs of the given society where that investment and trade has been conducted. Trade and investment with sustainable development is as a new approach to apply, which is pragmatic and progressive by analogy and text. A number of entrepreneurs have started utilizing untapped resources and working towards optimum utilization of such resources, which is encouraging. Naturally, their success does not satisfy the rest who are unable to compete. The threat that the excluded portion has created is higher in proportion to the profit earned by the entrepreneurs. Business giants that have accumulated wealth even greater that the government, but have no planning for development and sustainability of the resources is a major challenge. There is no best way to streamline development and investment for business and trade. A coherence model should be the priority. In this context, the present generation represents a pragmatic dimension and encourages upgrading policies and laws on that orientation. However, investment policy alone cannot provide a one-size-fits-all solution for all economies since it depends on the eco-socio-political conditions of individual countries.

Countries have different development strategies and each policy guide must acknowledge these divergences as well as the social, cultural, geographical and historical differences. The investment climate of each country has its own individual strengths and weaknesses. Thus policies should aim to build upon the existing strengths and reduce perceived deficiencies differently, mostly tuning on the specific economic contexts, sectoral investment priorities and development issues faced by individual countries. Every government is free to define priorities of investment and role for the foreign investors in 
their special context and are in need of industrial promotion, but these provisions must promote international norm and standards helpful for sustainable development practices. Despite the uniformity and conformity of international standard for inclusive investment and sustainable development, degrading and excessive exploitation of local sources must be caped until the sources become affluent for use or reuse. International communities must encourage nudging sustainability for forestation, charging resources and preserving or remerging water resource.

$* * * * * * * * * * *$ 